\title{
HUBUNGAN ANTARA PERKEMBANGAN PSIKOSOSIAL REMAJA DENGAN PERILAKU BULLYING DI SMAN 1 TOLITOLI
}

\section{The Relationship between Adolesencent Psychosocial Develpoment with Bullying Behavior in SMAN 1 Tolitoli}

\author{
Helena Pangaribuan*, Arifuddin, Lenny \\ Jurusan Keperawatan Poltekes Kemenkes Palu \\ *Email korespondensi: helenaesterpangaribuan@yahoo.co.id
}

\begin{abstract}
ABSTRAK
Remaja adalah fase masa transisi berada pada rentang usia 11-20 tahun. Perilaku bullying pada Remaja merupakan perilaku agresif yang dilakukan secara sengaja dan terjadi secara berulang-ulang untuk menyerang seorang target atau korban yang lemah, dihina dan tidak bisa membela diri sendiri dapat memberikan dampak negatif pada kehidupan individu, kehidupan akademik, kehidupan social bagi pelaku, korbannya dan saksi bullying, apabila tidak diatasi dengan baik beresiko terjadi penyimpangan perkembangan perilaku remaja yang negatif yang dapat mempengaruhi tahap tumbuh kembang berikutnya. Penelitian ini bertujuan untuk melihat Hubungan antara Perkembangan Psikososial remaja dengan Perilaku bullying di SMAN I Tolitoli. Desain pada penelitian ini adalah kuantitatif dengan 148 sampel menggunakan Proportionate Stratified Random Sampling dengan pendekatan cross sectional di uji dengan menggunakan chis-square. Hasil penelitian menunjukkan Sebanyak 30,4\% remaja perkembangan psikososialnya normal dan 69,6\% remaja perkembangan psikososialnya tidak normal, Siswa dengan perilaku yang melakukan prilaku bullying 59,5\% dan siswa dengan perilaku yang tidak melakukan perilaku bullying 40,5\%. Kesimpulan: terdapat hubungan antara perkembangan psikososial remaja dengan perilaku bullying remaja di SMAN I Tolitoli. Hasil didapatkan nilai sebesar 0,016, nilai tersebut lebih kecil dari nilai alpha 0,05. Diharapkan untuk Siswa perlu meningkatkan kreativitas remaja, pemberian penyuluhan kesehatan Orang tua dan pihak sekolah tentang bahaya prilaku bullying perlu untuk meningkatkan kesejahteraan dan kesehatan mental.
\end{abstract}

Kata Kunci: Bullying; Perkembangan Psikososial; Remaja.

\begin{abstract}
Adolescence is the phase of the transition periode in the age range of 11-20 years. Bullying behavior in adolescents is aggressive behavior that is done intentionally and occurs repeatedly to attack a target or victim who is weak, insulted and unable to defend himself, can have a negative impact on individual life, academic life, social life for perpetrators, victims and witnesses of bullying, if it is not properly addressed the risk of negative developmental behavior of adolescent behavior can affect the next stage of growth and development. This study aims to look at the relationship between the psychosocial development of adolescents and bullying behavior at SMAN I Tolitoli. Methodology: The design in this study was quantitative with 148 samples using the Proportionate Stratified Random Sampling with a cross sectional approach tested using chis-square. The results showed that $30.4 \%$ of adolescents had normal psychosocial development and $69.6 \%$ of adolescents had abnormal psychosocial development, students with behavior that carried out bullying behavior were $59.5 \%$ and students with behavior that did not conduct bullying behavior were $40.5 \%$. Conclusion: there is a relationship between the psychosocial development of adolescents and the bullying behavior of adolescents at SMAN I Tolitoli. The results obtained $p$ value of 0.016 , the value is smaller than the alpha value of 0.05 . It is hoped that for students to increase the creativity of adolescents, parents and schools provide health education about the dangers of bullying behavior
\end{abstract}

Keywords: Bullying; Psychosocial Development; Adolescents. 


\section{PENDAHULUAN}

Remaja (adolescence) adalah fase transisi berada pada rentang usia 11-20 tahun ${ }^{1}$. Remaja sangat menentukan masa depan bangsa dan pada masa ini remaja memasuki usia yang penuh dengan resiko tetapi juga menawarkan banyak kesempatan bagi remaja itu sendiri, keluarga dan lingkungan, Menurut Riskesdas, 2007 populasi remaja di dunia semakin meningkat, di Indonesia terdapat $20 \%$ remaja dari total penduduk. Menurut Depkes RI pada tahun 2008 jumlah remaja di Indonesia diperkirakan sudah mencapai 62 juta jiwa ${ }^{2}$. Tugas perkembangan Remaja harus dipenuhi dan bila tidak terpenuhi beresiko terjadi penyimpangan perkembangan jiwa dimasa yang akan datang ${ }^{3}$.

Menurut Maulana bahwa perilaku bullying adalah bentuk kenakalan remaja. Kenakalan remaja merupakan akibat yang ditimbulkan dari gangguan perkembangan psikososial pada ganguan perilaku yaitu perilaku remaja yang gemar melanggar aturan ${ }^{4}$.

Perkembangan psikososial remaja perlu mendapat perhatian, hal ini didasari oleh masalah yang banyak dialami oleh remaja disebakan oleh hubungan sosialnya disekolah yaitu bullying ${ }^{4}$.

Menurut Yusuf (2009) keamanan sekolah yaitu sejauh mana siswa merasa aman dan nyaman dengan lingkungan sekolahnya. siswa yang merasa aman selama berada di sekolah akan mempengaruhi performansi akademiknya, perilaku, sosio emosional dan kesejahteraan psikologisnya ${ }^{5}$.

Dalam kehidupan sehari-hari diperlukan Perhatian untuk Tindakan bullying Masih banyak yang menganggap bahwa bullying tidak berbahaya, padahal sebenarnya bullying dapat memberikan dampak negatif bagi pelaku korbannya dan saksi bullying ${ }^{6}$. Dampak yang dapat ditimbulkan akibat perilaku bullying bisa terjadi pada kehidupan individu, kehidupan akademik, kehidupan sosial ${ }^{7}$.

Perilaku bullying Remaja merupakan salah satu bentuk tindakan agresif. Secara umum Perilaku bullying merupakan perilaku agresif yang dilakukan secara sengaja dan terjadi secara berulang-ulang untuk menyerang seorang target atau korban yang lemah, mudah dihina dan tidak bisa membela diri sendiri ${ }^{7}$.

Bullying merupakan fenomena yang tersebar di seluruh dunia. Prevalensi bullying diperkirakan 8 hingga 50\% di beberapa negara Asia, Amerika, dan Eropa ${ }^{8}$. Hasil riset yang dilakukan oleh National Association of School Psychologist menunjukkan bahwa lebih dari 160.000 remaja di Amerika Serikat bolos sekolah setiap hari karena takut dibullying. Tujuh dari 10 anak di Indonesia pernah mengalami tindak kekerasan disekolah ${ }^{9}$. Menurut hasil kajian Konsorsium Nasional Pengembangan Sekolah tahun 2014, hampir setiap sekolah di Indonesia terjadi bullying dalam bentuk bullying verbal maupun bullying psikologis ${ }^{10}$. Sekitar $63,3 \%$ remaja sering berperilaku bullying di salah satu sekolah di Sulawesi Tengah ${ }^{11}$. Apabila kondisi ini tidak ditangani dengan baik dapat menyebabkan penyimpangan perkembangan remaja, depresi dan resiko gangguan kejiwaan. Tujuan penelitian ini untuk mengetahui Hubungan antara Perkembangan Psikososial dengan Perilaku bullying di SMAN 1 Tolitoli.

\section{METODE PENELITIAN}

Penelitian ini menggunakan desain penelitian korelasi. pendekatan yang digunakan adalah cross sectional, tehnik pengambilan sampel secara Proportionate Stratified Random Sampling, metode ini perpanjangan dari teknik Simple Random Sampling. Populasi yang digunakan dalam penelitian ini adalah semua remaja di SMAN 1 Tolitoli, Penelitian ini menggunakan analisa analisa Univariat digunakan untuk mendiskripsikan masingmasing variable, analisa Bivariat digunakan untuk mengetahui hubungan antara perkembangan pesikososial remaja dan perilaku bullying remaja. Penelitian ini menggunakan uji statistik Chi-Square. Untuk mengetahui kekuatan atau keeratan hubungan dua variabel.

\section{HASIL PENELITIAN}

Penelitian ini dilaksanakan di Sekolah di SMAN 1 Tolitoli pada bulan April dan Mei 2017 selama lima minggu. Penelitian ini dilaksanakan dengan menggunakan responden anak kelas X dan XI (usia 15-18 tahun) dengan jumlah sampel 148 responden. Data diperoleh melalui lembaran kuesioner yang terdiri dari karakteristik responden serta kuesioner perkembangan psikososial dan perilaku bullying. 
Tabel 1. Distribusi Frekuensi Remaja berdasarkan jenis kelamin, usia, kelas, perkembangan psikososial, dan perilaku bullying

\begin{tabular}{lrr}
\hline \multicolumn{1}{c}{ Variabel } & Jumlah & \% \\
\hline Jenis Kelamin & & \\
\hline Laki-laki & 64 & 43,2 \\
Perempuan & 84 & 56,8 \\
\hline Usia & & \\
\hline 15 tahun & 60 & 40,5 \\
16 tahun & 70 & 47,5 \\
17 tahun & 15 & 10,0 \\
18 tahun & 3 & 2,0 \\
\hline Kelas & & \\
\hline Kelas X & 77 & 52,2 \\
Kelas XI & 71 & 47,8 \\
\hline
\end{tabular}

\begin{tabular}{lrr}
\hline \multicolumn{1}{c}{ Variabel } & Jumlah & \% \\
\hline Perkembangan & & \\
\hline Normal & 45 & 30,4 \\
Tidak normal & 103 & 69,6 \\
\hline Perilaku bullying & & \\
\hline Negatif & 60 & 40,5 \\
Positif & 88 & 59,5 \\
\hline
\end{tabular}

Tabel 1 menunjukkan bahwa dari 148 remaja terdapat 56,8\% dengan jenis kelamin perempuan. Distribusi frekuensi remaja berdasarkan usia dari 148 terdapat $47,5 \%$ pada usia 16 tahun dan dari 247 terdapat $52,2 \%$ dari kelas X. Sejumlah $69,6 \%$ perkembangan psikososial remaja kategori tidak normal serta terdapat $59,5 \%$ siswa melakukan bullying positif.

Tabel 2 Tabulasi Silang antara Perkembangan Psikososial Remaja dengan Perilaku Bullying Remaja

\begin{tabular}{|c|c|c|c|c|c|c|c|}
\hline \multirow{3}{*}{$\begin{array}{c}\text { Perkembangan } \\
\text { Psikososial }\end{array}$} & \multicolumn{6}{|c|}{ Perilaku bullying } & \multirow{3}{*}{ Nilai $p$} \\
\hline & \multicolumn{2}{|c|}{$\begin{array}{c}\text { Negatif } \\
\text { (tidak Bullying) }\end{array}$} & \multicolumn{2}{|c|}{$\begin{array}{c}\text { Positif } \\
\text { (melakukan } \\
\text { Bullying } \\
\end{array}$} & \multicolumn{2}{|c|}{ total } & \\
\hline & $\mathbf{n}$ & $\%$ & n & $\%$ & n & $\%$ & \\
\hline Normal & 12 & 26,7 & 33 & 73,3 & 45 & 100,0 & \\
\hline Tidak Normal & 48 & 46,6 & 55 & 53,4 & 103 & 56,9 & 0,010 \\
\hline Total & 60 & 40,5 & 88 & 59,5 & 148 & 100 & \\
\hline
\end{tabular}

Tabel 2 menunjukan tabel silang antara perkembangan psikososial remaja dengan perilaku Bullying remaja. Hasil analisa statistik tabulasi silang menunjukan bahwa remaja dengan perkembangan psikososial normal dengan perilaku Bullying negatif sebanyak 12 remaja (26,7\%). Remaja yang memiliki perkembangan psikososial normal dengan perilaku Bullying positif sebanyak 33 remaja (73,3\%). Remaja yang memiliki perkembangan psikososial tidak normal dengan perilaku Bullying negatif sebanyak 48 remaja $(46,6 \%)$. Sedangkan 55 remaja $(53,4 \%)$ memiliki perkembangan psikososial yang tidak normal dengan perilaku bullying positif. Hasil analisis statistik hubungan yang signifikan antara perkembangan psikososial remaja dengan perilaku bullying remaja dilakukan dengan uji Chi-Square diperoleh $p$ value sebesar 0,016. Nilai tersebut lebih kecil dari nilai alpha $(0,05)$, dapat disimpulkan bahwa ada hubungan antara perkembangan psikososial remaja dengan perilaku bullying remaja di SMAN I Tolitoli. Berarti remaja dengan perkembangan psikososial normal memiliki distribusi melakukan perilaku bullying yang tinggi namun remaja dengan perkembangan psikososial yang tidak normal distribusi melakukan perilaku bullying lebih tinggi lagi.

\section{Pembahasan \\ Perkembangan Psikososial Remaja}

Hasil penelitian pada menunjukkan sebanyak 56,9\% remaja berada dalam kategori psikososial tidak normal. Hal ini menunjukan bahwa sebagian besar remaja mengalami perkembangan psikososial yang tidak normal. Gambaran perkembangan psikososial remaja yang tidak normal ini antara lain, menunjukan bahwa remaja ingin terlihat sama dengan teman sekelompoknya dari cara pakaian, gaya rambut dan gaya hidup, ingin mengubah 
rambut, baju, sikap dan pendapat dalam waktu singkat, tidak suka mengikuti diskusi atau debat, ingin bebas mengekspresikan perasaan pada tanpa ada ikut campur orang lain.

Remaja masih membutuhkan bimbingan serta arahan dari orangtuanya. Kurangnya kontrol tersebut mengakibatkan remaja bebas melakukan hal yang disenanginya seperti suka berganti gaya rambut, baju, sikap dan pendapatnya dalam waktu singkat meskipun terkadang terkesan di paksakan tetapi karena alasan remaja tersebut tidak ingin kehilangan teman bermainnya sehingga mereka cendrung melakukan apa yang teman mereka lakukan. Hal tersebut sesuai dengan teori bahwa perkembangan psikososial yang terjadi pada remaja dapat dipengaruhi oleh faktor keluarga, lingkungan teman sebaya serta konsep diri yang positif.

Remaja yang tidak memiliki konsep diri positif maka dirinya tidak memiliki pengetahuan tentang dirinya serta tidak dapat mengenali siapa dirinya sehingga remaja tersebut tidak mempunyai penerimaan diri, penyesuaian diri dan sosial yang tidak baik pula. Menurut Keliat bahwa semakin rendah konsep diri yang dimiliki remaja maka akan semakin tinggi keinginan remaja sama dengan kelompok teman sebayanya ${ }^{12}$.

\section{Perilaku bullying Remaja}

Sebagian besar remaja dalam penelitian ini melakukan perilaku bullying. Beberpa penelitian pun menunjukan hal yang sama dimana mereka yang membully lebih dari separuh remaja ${ }^{11}$. Gambaran perilaku bullying yang dilakukan di SMAN 1 Tolitoli, menunjukan bahwa sebagian besar remaja perilaku bullying pada penelitian ini yang lebih tinggi bullying Verbal dan psikologis. Bullying terjadi saat seseorang mengalami bentuk pelecehan dan penghinaan secara meyakinkan selama periode waktu yang cukup lama (9-16 hari dalam satu bulan). Tindakannya dalam meliputi ejekan yang kejam, pengucilan yang berkelanjutan dan beberapa ancaman dan serangan fisik yang halus, contohnya mendorong, menjegal, menarik baju ${ }^{13}$. Perilaku bullying sedang dalam penelitian ini juga mengidentifikasi bahwa rasa saling mengharagi antara siswa masih kurang. Guru dan lingkungan sekolah yang kurang baik, pengawasan dan etika yang kurang serta kurang menjunjung tinggi nilai-nilai agama yang lebih mendalam.
Perilaku Bullying maupun seseorang yang mengalami bullying sangat berpengaruh pada psikososialnya, anak yng memiliki kepribadian introvert dan ekstrovert akan lebih mudah berpeluang mendapatkan perlakuan bullying maupun sebagai pembully. Maka dari itu kepribadian anak juga sangat berpengaruh pada perilkau bullying maupun kemampuan interaksi sosialnya, banyak ditemukan bahwa sering jadi Korban bullying kemampuan interaksinya rendah, seseorang yang jarang dibully interaksi sosialnya cukup.

Hal ini sesuai dengan teori yang menyatakan bahwa perilaku bullying yang dilakukan remaja ini bisa disebabkan beberapa faktor diantaranya adalah faktor internal dan faktor eksternal. Faktor internal berupa kontrol diri pada individu sedangkan faktor eksternal dipengaruhi oleh lingkungan/teman dan media massa. Kontrol diri merupakan suatu kemampuan menyusun, membimbing, mengatur dan mengarahkan bentuk perilaku yang dapat membawa individu kearah konsekuensi positif. keadaan ini sesuai dengan teori bahwa perilaku bullying yang terjadi pada remaja dapat dipengaruhi oleh faktor internal yang berupa keharmonisan keluarga. Keharmonisan keluarga tidak akan tercapai apabila terjalin hubungan yang baik seperti komunikasi antara anak dan orangtua, jika adanya komunikasi yang baik antara anak dengan orangtuanya maka orang tua dapat mengontrol kejadian dan perkembangan apa yang sedang dialami anaknya, orang tua dapat diberikan informasi tentang pendidikan tentang bullying pada remaja dan ada dampak yang akan ditimbulkan jika dilanggar. kondisi keluarga yang harmonis dapat membantu terbentuknya sikap negatif pada remaja terhadap bullying.

Dukungan keluarga khususnya orang tua yang memberikan kasih sayang memperhatikan perkembangan kemampuan anaknya, dan memperhatikan minat anaknya menjadikan remaja dapat menilai siapa dirinya sehingga untuk melakukan hal yang tidak sesuai yang dengan aturan dalam keluarganya akan segan untuk melanggar dan remaja akan memiliki konsep diri tinggi sehingga remaja dapat bersosialisasi dengan baik.

\section{Hubungan antara Perkembangan Psikososial dengan Perilaku bullying}

Hasil penelitian ini menunjukan bahwa perkembangan psikososial remaja dalam 
kategori normal dengan perilaku bullying atau melakukan bullying.

Remaja dengan perkembangan psikososial normal memiliki distribusi melakukan bullying yang tinggi namun remaja dengan perkembangan psikososial yang tidak normal distribusi melakukan perilaku bullying lebih tinggi lagi. Remaja pertengahan usia 15- 18 tahun merupakan masa dimana remaja dengan emosi dan kepribadian masih labil karena masih mencari jati diri sehingga rentan terhadap lingkungan pergaulannya. Perilaku bullying di SMAN 1 Tolitoli disebabkan karena faktor internal dan eksternal. Perilaku bullying tidak akan terjadi jika remaja memiliki perkembangan psikososial yang baik. Perkembangan psikosial yang terjadi dipengaruhi oleh kontrol diri yang positif, faktor keluarga dan lingkungan teman sebaya. Hal yang paling utama yang mempengaruhi remaja untuk melakukan bullying adalah konsep diri yang positif. Konsep diri merupakan suatu pegangan hidup sesorang untuk dapat menilai, menafsirkan perilaku yang dilakukan. Artinya jika remaja memiliki konsep diri yang positif maka mereka tidak akan melakukan perilaku bullying.

Perilaku bullying pada remaja akibat perubahan hormon dan pengaruh lingkungan. Pengendalian tersebut dapat dikendalikan dengan cara konsep diri yang baik yang harus dimiliki oleh remaja. Hal ini sesuai hasil penelitian yang dilakukan oleh Ratna bahwa jika semakin rendah konsep diri yang dimiliki remaja maka semakin tinggi perilaku bullying ${ }^{14}$.

Hasil analisis peneliti tentang penelitian ini yaitu, remaja dengan perkembangan psikososial normal memiliki distribusi melakukan bullying yang tinggi namun remaja dengan perkembangan psikososial yang tidak normal distribusi melakukan perilaku bullying lebih tinggi lagi.

Dalam penelitian ini didapatkan hubungan antara perkembangan psikososial remaja dengan perilaku bullying remaja. Agar remaja terhindar dari perilaku bullying maka remaja harus mampu menyesuaikan diri, mencapai kedewasaan dengan kemandirian, kepercayaan untuk menghadapi kehidupan, mencapai posisi yang diterima oleh masyarakat, memecahkan masalah- masalah dalam pengalaman sendiri dalam kaitannya dengan lingkungan khususnya keluarga. Dukungan keluarga yang harmonis khususnya orang tua yang memberikan kasih sayang memperhatikan perkembangan kemampuan anaknya apat membantu terbentuknya sikap negatif pada remaja terhadap bullying.

\section{KESIMPULAN DAN SARAN}

Penelitian ini menyimpulkan sebanyak $43,1 \%$ remaja perkembangan psikososialnya normal dan $69,6 \%$ remaja perkembangan psikososialnya tidak normal. Siswa dengan perilaku yang melakukan perilaku bullying $59,5 \%$ dan siswa dengan perilaku yang tidak melakukan prilaku bullying $40,5 \%$. Terdapat hubungan antara perkembangan psikososial remaja dengan perilaku bullying remaja. Penelitian ini diharapkan untuk Siswa perlu meningkatkan kreativitas remaja, pemberian penyuluhan kesehatan Orang tua dan pihak sekolah tentang bahaya prilaku bullying, perlu untuk meningkatkan kesejahteraan dan kesehatan mental.

\section{DAFTAR PUSTAKA}

1. Sacco, R. G. Re-Envisaging the Developmental stages of erick erickson: The fibonacci life-chart method (FLCM). Journal of Educational and Depelopmental Pschology, 3(1), 140-146. 2013.

2. Depkes. Riset kesehatan dasar 2007: www.litbang.depkes.qo.id/Laporan RKD/Indonesianasional. 2007.

3. Stuart, Gail W. Principles and Practice of Psychiatric Nursing. $9^{\text {th }}$ ed. Mosby Inc. 2005.

4. Maulana HDJ. Promosi Kesehatan. Jakarta: Egc; 2009.

5. Yusuf. Psikologi perkembangan anak dan Remaja. Bandung : PT Remaja. 2009.

6. Wiyani, A. Save our Children From School Bullying . Jogjakarta : Arruz Media. 2012.

7. Sejiwa. Bullying: Mengatassi Kekerasan di Sekolah dan Lingkungan Sekitar Anak. Jakarta. Grasindo. 2008.

8. Soedjatmiko. Nurhamzah, W. Maureen, A. Wiguna, T. Gambaran Bullying dan Hubungan dengan Masalah Emosi dan Perilaku pada Anak Sekolah Dasar. Jurnal Sari Pediatri, Vol. 15. No.3, 175. 2013.

9. Hamid. (2009). Bunga Rampai. Asuhan eperawatan Kesehata Jiwa, Jakarta: EGC.

10. Setyawan, D. KPAI: Pelaku Kekerasan Terhadap Anak Tiap Tahun Meningkat. 2015. http://www.kpai.go.id/berita/kpai-pelakukekerasan-terhadap-anak-tiap-tahunmeningkat/. 
11. Ramadhan K, Estevani E, Entoh C, Nurfatimah N. Mekanisme Koping Individu dan Perilaku Bulying pada Siswa SMA. J Kesehat Manarang. 2019 Jul 31;5(1):14. Available from: http://jurnal.poltekkesmamuju.ac.id/index.php/ $\mathrm{m} /$ article/view/86

12. Keliat,B.A., Helena. N., Farida,P. Manajemen Keperawatan Psikososial \& Kader Kesehatan Jiwa (CMHN). EGC: Jakarta. 2011.
13. Rigby, K. Children and bullying. how parents and educators can reduce bullying at school. California: Blackwell Publishing. 2008.

14. Ratna Djuwita, 'Kekerasan Tersembunyi Di Sekolah: Aspek-Aspek Pdikososial Dari Bullying-Victims: A Comparison of Psychosocial and Behavioral Characteristics', Journal of Pediatric Psychology, 2006. 